\title{
Woody Plant Inventory and Its Management Practices in Traditional Agroforestry of West Hararghe Zone, Oromia National Region State, Ethiopia
}

\author{
Husen Yusuf*, Tibebu Solomon \\ Department of Natural Resource Management, University of Oda Bultum, Chiro, Ethiopia
}

Email address:

hudhmabaci@gmail.com (H. Yusuf)

${ }^{*}$ Corresponding author

\section{To cite this article:}

Husen Yusuf, Tibebu Solomon. Woody Plant Inventory and Its Management Practices in Traditional Agroforestry of West Hararghe Zone, Oromia National Region State, Ethiopia. American Journal of Environmental Protection. Special Issue: Enhancing Natural Resource Conservation for Sustainable Development. Vol. 8, No. 5, 2019, pp. 94-103. doi: 10.11648/j.ajep.20190805.11

Received: August 19, 2019; Accepted: September 29, 2019; Published: October 30, 2019

\begin{abstract}
This study was conducted in west Hararghe zone with the main objective of documenting the woody species and identifying its management in major traditional Agroforestry practices. The research was carried out between February 1, 2018-June 30 2018. In this study, total of 18 peasant associations in 6 rural districts were selected by multistage sampling in which 600 household heads were selected using random sampling techniques. Qualitative data were generated by conducting household survey interviews. The farm plot of each household was equated to an ecological sampling unit for gathering bio-physical data. Focus group discussions, key informant interview, and direct field observations were also applied to get additional data. All the collected data were manipulated using Statistical Package for Social Sciences (SPSS) version 20 and Microsoft Office Excel 2007 to calculate descriptive statistics, such as means, percentages and frequency. A number of Compositions of woody species in major traditional agroforestry practices in study site were observed and counted. In total, 68 woody tree species representing 31 families were recorded. In the study area family Fabaceae was a predominant with the total species of $20(29.4 \%)$. The species can also categorized into three based on their provenance, 18 species are introduced 2 species are endemic to Ethiopia and the majority 48 species are indigenous. The common management practices of the woody species in the study area include branch pruning, coppicing, thinning, pollarding and protection from animal damage. The result of the current study shown that there are varies traditional agroforestry management in the study area. Woody plant species composition on each traditional agroforestry practices was also identified and recorded. Finally, existing woody plant species should be conserved, and the importance of each and every potential tree species in the study area for soil fertility improvement, animal feed, biological soil conservation, and ecological importance needs further study.
\end{abstract}

Keywords: Agroforestry, Woody Species, Management Practice, Inventory

\section{Introduction}

Traditional agroforestry land use should be viewed as a household strategy for providing food, fuel wood and fodder that could serve as a model for sustainable forestry and agricultural practices [1]. It has been practiced in Ethiopia since time immemorial by villagers on farm lands. It is recognized worldwide as a sustainable system characterized by the production of multiple species closely arranged in several overlapping canopy layers and in association with livestock [2]. This integrated land use systems are believed to enhance agriculture due to the association between multiple crops and trees on one hand, and various ecological and economic benefits on the other. According to World Agroforestry Center, agroforestry is a dynamic, ecological-based natural resources management system through integration of trees into rangeland and farmland to diversify and sustain production for the increasing socio-economic and environmental benefits for all land users at all levels [3]. 
Including West Hararghe area where this study was conducted, agroforestry is a major component of Ethiopian farming systems and recently taken as one of the development objectives in PASDEP of national development policy of the country [4]. It becomes one of the common features in watershed management especially in the highlands of Ethiopia. This is also true in West Hararghe Zone, that traditional agroforestry practices have been a main feature in the Zone and serving numerous protective and productive functions in both up streamers and lower catchments since; woody perennials have huge potential for this. In the agroforestry system, woody perennials are either deliberately retained or planted on the farmland [5]. Deferent agroforestry systems require deferent periods of time to develop and manage. Therefore, depending on deferent benefits obtained from the system, farmers could employ deferent kinds of component management in the system. The common managements in tropical agroforestry system are pruning, prescribed burning, thinning, pollarding, grass mulch application, crop residue application, watering, and coppicing [6].

In the management of agroforestry the indigenous knowledge of local people is important, and in order to scale up the deferent agroforestry practices an appreciation of indigenous knowledge is needed [3]. Indigenous knowledge includes deferent sets of complex practices. The discovery of knowledge in managing resource is made by local people. Then, the knowledge exhibited and experienced will be transferred to generations with some modifications [7]. Therefore, understanding the historical development of indigenous systems is decisive in the design of ecologically desirable agroforestry production systems [8]. In general indigenous knowledge of local people are not simply producers, they are also engaged in pursuit of knowledge. Most development interventions in the past failed due to lack of giving adequate attention to indigenous knowledge [9].

The existence of woody species in traditional Agroforestry practices is a great potential for further development and the introduction of new agroforestry systems. In West Hararghe Zone, agroforestry woody species is practiced by the farmers; however no study has been conducted so far on woody species inventory and their management practices. Thus the current research was initiated with overall objective of to document the woody species and understand its management in major traditional agroforestry practices which will be used as base line data for further development and research activities.

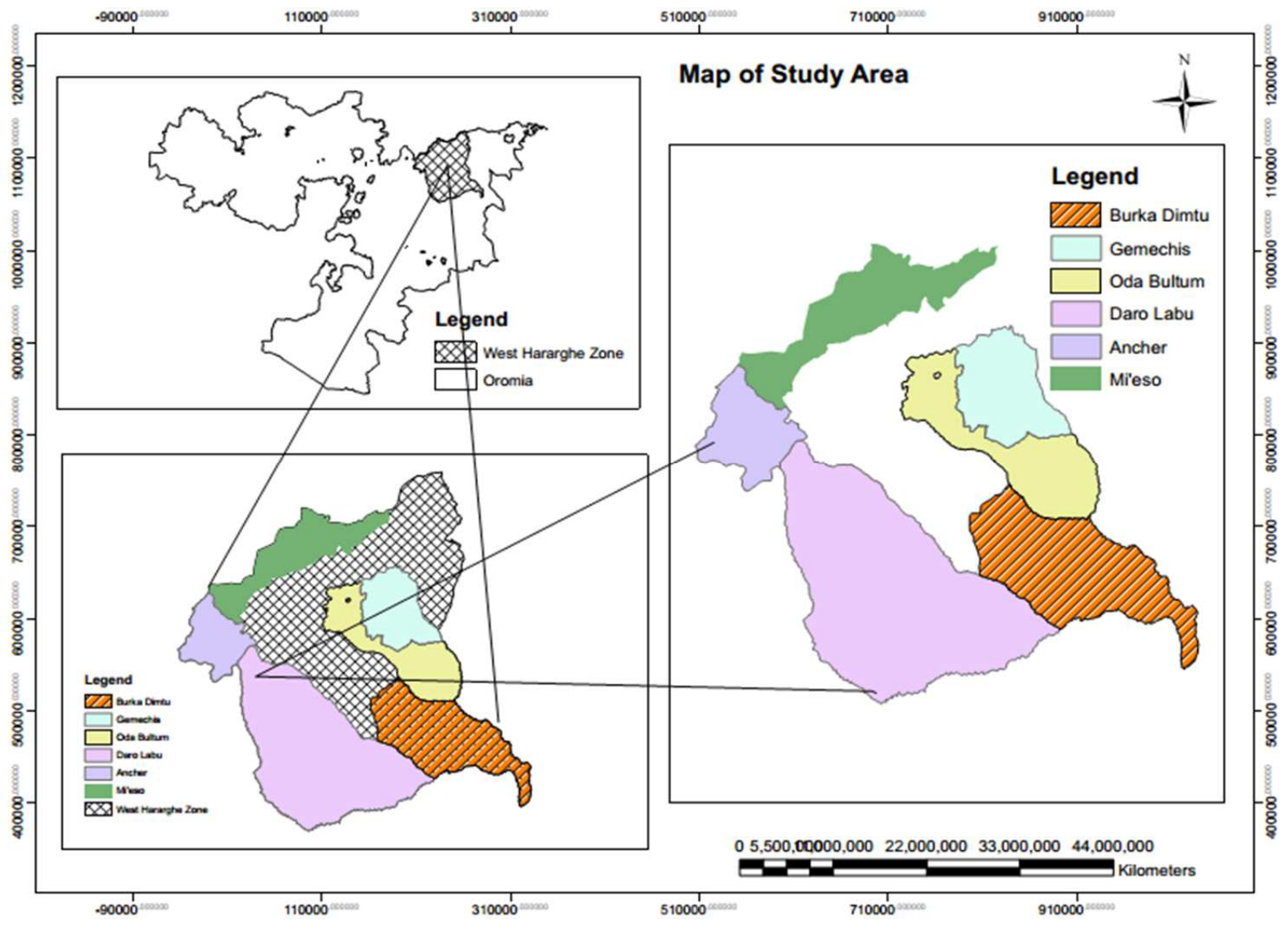

Figure 1. Map of study Area.

\section{Research Methodology}

\subsection{Description of the Study Area}

West Harerghe Zone is one of the 17 Zones in Oromia
National Regional State, geographically located between 70 $52^{\prime} 15^{\prime \prime}$ - 90 28' 43" North latitude and 400 03' 33" - 400 34' 13" East longitudes. The zone is bordered in the South by the Shebelle River which separates it from Bale zone, on the Southwest by Arsi zone, on the Northwest by the Afar 
National Regional State, on the North by the Somali National Regional State and on the East by East Harerghe zone. Towns in West Harerghe include Chiro, Bedessa, Gelemso and Mieso. The capital town of the Zone is Chiro, which is located at a distance of $326 \mathrm{~km}$ East of Addis Ababa. The area coverage of the Zone is 1,723,145 ha $\left(17,231 \mathrm{~km}^{2}\right)$, comprising of 15 districts with a combined population of $1,871,706$ persons, of whom 912,845 are women. While 160,895 or 9.36 percent are urban inhabitants, a further 10,567 or 0.56 percent are pastoralists and semi-pastoralists West Harerghe is subdivided in to three major climatic zones known to be temperate tropical highland, locally known as dega (12.49\%), semitemperate/tropical rainy mid land or woina dega $(38 \%)$, and semi-arid/tropical dry or kola (49.5\%) [10].

\subsection{Methods of Data Collection and Source}

Data was collected from household interviews, key informant interviews, focal group discussion and direct field observation (table 2). The criteria of selecting of sample districts and peasant associations are based on agro ecology and potential of traditional agroforestry practices. Accordingly, (Gemechis \& Hancar districts) from highland agro ecology, (Darolabu \& Oda Bultum districts) from mid land agro ecology and (Mieso \& Burka dhimtu districts) from lowland agro ecology were selected.

Thus, informants were selected by applying the sample determination formula

$$
\mathrm{n}=\frac{\mathrm{z}^{2} \mathrm{pq}}{\mathrm{d}^{2}}
$$

to the 139,426 households [11] living in the six administrative districts of western Hararghe zone. Where $\mathrm{d}=$ 0.04. As the administrative districts were not of equal size, where $95 \%$ degree of confidence interval was used in the current study. We converted the confidence level to a $\mathrm{Z}$ score which is 1.96 and confidence. We expected 50 percent respondents to respond affirmatively since such kind of research is never conducted previously in the area, 0.5 would be the proportion. We computed the needed sample size by plugging the values into the above formula, where $\mathrm{Z}$ is the $\mathrm{Z}$ score, $\mathrm{P}$ is the proportion and $\mathrm{d}$ is the confidence interval. Sample Size needed $=(1.96)^{2} \times 0.5(1-0.5) /(0.04)^{2}=$ $(3.8416 \times 0.25) / 0.0016=0.9604 / 0.0016=600.25$

The calculated sample size was distributed to the six administrative districts by proportional allocation as given by

$$
\mathrm{n}_{\mathrm{h}}=\frac{\mathrm{nN}_{\mathrm{h}}}{\mathrm{N}}
$$

Where $\mathrm{n}=$ the total number of sample households,

$\mathrm{N}_{\mathrm{h}}=$ total number of households in the administration zone, and

$\mathrm{N}=$ the total number of households in the overall study area, in six sample districts of western Hararghe zone. This method has been recommended for research that depends somewhat on the relative costs of sampling more units compared with sampling more elements [12].

The first step in gathering quantitative ethno-botanical data is free listing, i.e, delimiting the domain that interests us and asking community members to list the names of plants belonging to the domain. In this study, informants were asked to give a list of tree species growing in their farm plots following [13]. Woody species inventory was carried out to record all woody found in the traditional agroforestry practices. The farmland of sample households was used as a sample plot for inventory. Local name of all woody species found in the sample plots were recorded by the help of local community and identification of the scientific names of species were carried out using two books as a guideline [14, $15]$.

\begin{tabular}{|c|c|c|c|c|c|c|}
\hline Name of districts & $\begin{array}{l}\text { No. of rural peasant } \\
\text { associations }\end{array}$ & No. of sample PA & $\begin{array}{l}\text { Selected peasant } \\
\text { associations }\end{array}$ & $\begin{array}{l}\text { PA total } \\
\text { population }\end{array}$ & $\begin{array}{l}\text { No. of total peasant } \\
\text { associations HH }\end{array}$ & $\begin{array}{l}\text { No. of sampled } \\
\text { informants } \\
\end{array}$ \\
\hline \multirow{3}{*}{ Gemechis } & \multirow{3}{*}{35} & \multirow{3}{*}{3} & Sororo & 3666 & 607 & 43 \\
\hline & & & Madara & 5134 & 903 & 65 \\
\hline & & & Waltane & 2865 & 501 & 36 \\
\hline \multirow[b]{2}{*}{ Hancar } & \multirow[b]{2}{*}{38} & \multirow[b]{2}{*}{3} & Dindin & 6381 & 1060 & 32 \\
\hline & & & Midhegdu & 3297 & 559 & 17 \\
\hline \multirow{3}{*}{ Darolabu } & \multirow{3}{*}{40} & \multirow{3}{*}{3} & Matagudesa & 3104 & 524 & 19 \\
\hline & & & Caffe hara & 5641 & 926 & 34 \\
\hline & & & Kortu & 4587 & 814 & 29 \\
\hline \multirow{3}{*}{ Oda Bultum } & \multirow{3}{*}{37} & \multirow{3}{*}{3} & Jawis & 5971 & 986 & 44 \\
\hline & & & Ido bariso & 5900 & 973 & 43 \\
\hline & & & Oda baso & 4492 & 787 & 35 \\
\hline \multirow{2}{*}{ Mieso } & \multirow{2}{*}{35} & \multirow{2}{*}{3} & Husehadami & 3256 & 542 & 29 \\
\hline & & & Husemandhera & 3564 & 608 & 33 \\
\hline \multirow{3}{*}{ Burka dimtu } & \multirow{3}{*}{36} & \multirow{3}{*}{3} & Tayfe & 4028 & 692 & 30 \\
\hline & & & Rukesa ifa & 4262 & 725 & 31 \\
\hline & & & Anuba & 3763 & 614 & 26 \\
\hline Total & 221 & 18 & & 77,401 & 13,063 & 600 \\
\hline
\end{tabular}

Table 1. Number of sampling districts, peasant associations and informants. 
Table 2. Summary and descriptions of instruments by type, target and number of target group representations for data collection.

\begin{tabular}{|c|c|c|c|c|c|}
\hline No & Type of Instruments & Target groups & $\begin{array}{l}\text { Number of } \\
\text { Representations }\end{array}$ & Type of Sampling & Remark \\
\hline 1 & Key informants Interview & $\begin{array}{l}\text { Long residence and Knowledgeable community } \\
\text { members }\end{array}$ & 90 & Purposive Sampling & Each for PA \\
\hline 2 & Focus group Discussions & Gender group, expert and officials & 36 & Purposive Sampling & Each for district \\
\hline 3 & Household survey & randomly selected farmers from households head & 600 & Simple random & \\
\hline 4 & Direct field observation & Model field & 24 & Purposive Sampling & 3 for each \\
\hline 5 & Total & & 750 & & \\
\hline
\end{tabular}
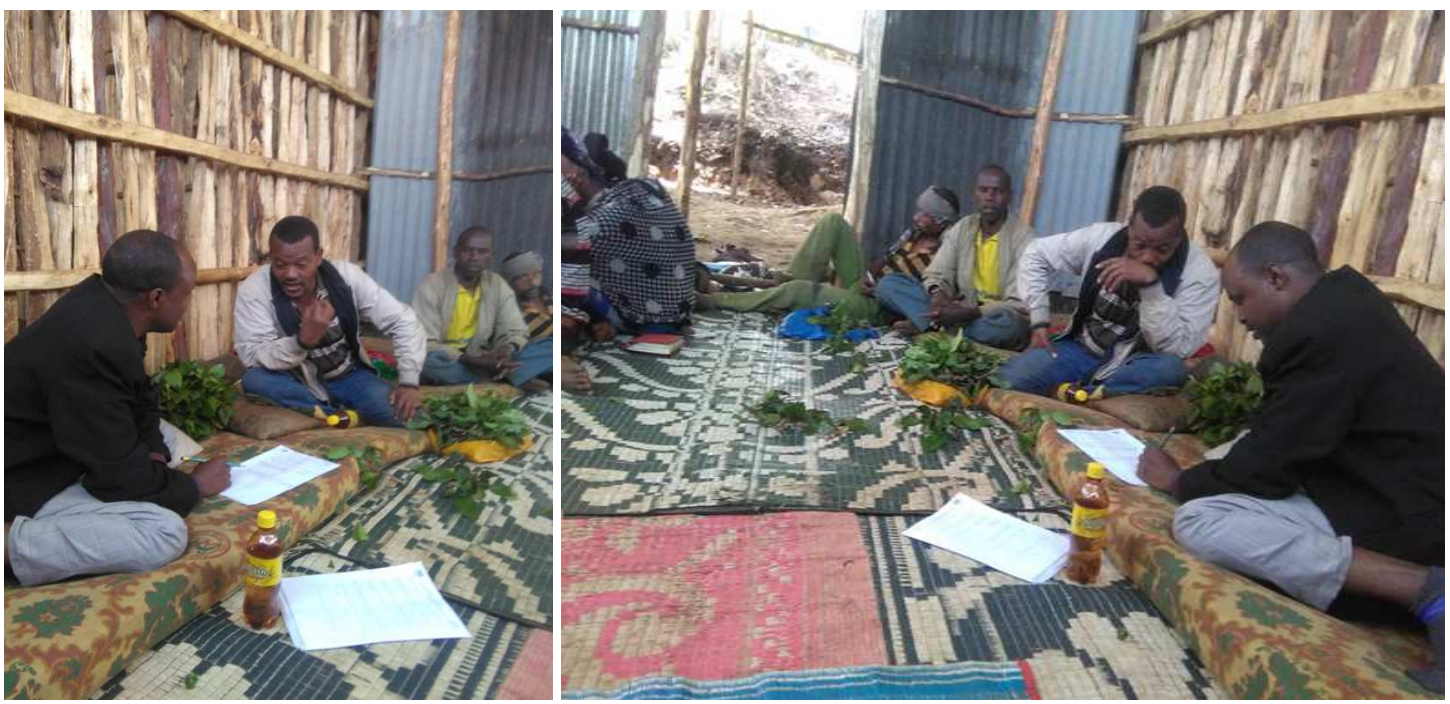

Figure 2. Researcher during focus group discussion

\subsection{Data Analysis}

The field data collected from informants and farm plots was edited and presented in quantitative terms for analysis using appropriate descriptive statistical analysis. Simple quantitative analysis techniques such as percentage and frequency distributions were employed. Data entry and simple arithmetic calculations were conducted using (Excel 2007 and SPSS version 20). Finally the results were summarized in a table form so that the analysis and meaningful interpretations of results was made to draw conclusions and implications. The qualitative data collected through key informant interview, focus group discussion and physical observation was narrated and summarized.

\section{Results and Discussion}

\subsection{Household Characteristics of Sampled Households}

A total of 600 households, comprising 465 male (78\%) and 135 (22\%) female were interviewed. Household characteristics of sample households per district are presented in Table three below. Generally, traditional agroforestry practices are mostly done by men because of the cultural values and responsibilities of men in west Hararghe families. As it is clearly seen from Table 3, there appears to be a higher proportion of middle age group household in the study site whereas younger and older households are represented only in smaller portion. Majority of them (55\%) were between 25 and 54 years. Therefore, the study found out that the populations of the surveyed areas were dominated by working age group and was similar to reports by earlier researchers which show that younger farmers are more likely to adopt a new technology [2]. The results of this study show that average family size per individual farmers is five to ten $(62 \%)$. Increasing population number forced the farmers to manage agroforestry practices at plot level. On the other hand, the respondents mentioned as having benefited from this increasing family size for labor availability. The study findings are in consistent with those of study carried out in Sebeta-Hawas district, Southwestern Shewa Zone of Oromia Region, found out that, large household size positively influences of labor- demanding agriculture like, agroforestry since they have the ability to relax the labor limitations necessary [2].

Table 3. Household Characteristics of sample households.

\begin{tabular}{|c|c|c|c|c|c|c|c|c|c|}
\hline \multirow{2}{*}{$\begin{array}{l}\text { Socio-economic } \\
\text { variable }\end{array}$} & \multirow{2}{*}{ Definition of variables } & \multicolumn{6}{|c|}{ Sample districts in study site } & \multirow{2}{*}{ Total } & \multirow{2}{*}{$\begin{array}{l}\text { \% of } \\
\text { Respondents }\end{array}$} \\
\hline & & Gemechis & Hancar & Darolabu & Odabultum & Mieso & Burkdhimtu & & \\
\hline \multirow{3}{*}{ Sex } & Male & 100 & 53 & 63 & 89 & 84 & 76 & 465 & 78 \\
\hline & Female & 44 & 11 & 19 & 33 & 17 & 11 & 135 & 22 \\
\hline & Total & 144 & 64 & 82 & 122 & 101 & 87 & 600 & 100 \\
\hline
\end{tabular}




\begin{tabular}{|c|c|c|c|c|c|c|c|c|c|}
\hline \multirow{2}{*}{$\begin{array}{l}\text { Socio-economic } \\
\text { variable }\end{array}$} & \multirow{2}{*}{ Definition of variables } & \multicolumn{6}{|c|}{ Sample districts in study site } & \multirow{2}{*}{ Total } & \multirow{2}{*}{$\begin{array}{l}\text { \% of } \\
\text { Respondent }\end{array}$} \\
\hline & & Gemechis & Hancar & Darolabu & Odabultum & Mieso & Burkdhimtu & & \\
\hline \multirow{5}{*}{ age in year } & $18-24$ & 28 & 17 & 18 & 27 & 22 & 15 & 127 & 21 \\
\hline & $25-54$ & 79 & 35 & 42 & 59 & 61 & 58 & 334 & 55 \\
\hline & $55-64$ & 23 & 8 & 18 & 21 & 10 & 8 & 88 & 15 \\
\hline & $>65$ & 14 & 4 & 4 & 15 & 8 & 6 & 51 & 9 \\
\hline & Total & 144 & 64 & 82 & 122 & 101 & 87 & 600 & 100 \\
\hline \multirow{5}{*}{$\begin{array}{l}\text { House hold } \\
\text { marital status }\end{array}$} & Married & 84 & 50 & 65 & 74 & 64 & 66 & 403 & 67 \\
\hline & Widowed & 13 & 4 & 8 & 13 & 12 & 15 & 65 & 11 \\
\hline & separated/Divorced & 34 & 5 & 3 & 27 & 21 & 5 & 95 & 16 \\
\hline & Single & 13 & 5 & 6 & 8 & 4 & 1 & 37 & 6 \\
\hline & Total & 144 & 64 & 82 & 122 & 101 & 87 & 600 & 100 \\
\hline \multirow{4}{*}{$\mathrm{HH}$ family size } & $<5$ & 46 & 19 & 26 & 47 & 39 & 29 & 206 & 34 \\
\hline & $5-10$ & 94 & 42 & 56 & 73 & 56 & 49 & 370 & 62 \\
\hline & $>10$ & 4 & 3 & 0 & 2 & 6 & 9 & 24 & 4 \\
\hline & Total & 144 & 64 & 82 & 122 & 101 & 87 & 600 & 100 \\
\hline \multirow{6}{*}{$\begin{array}{l}\mathrm{HH} \text { educational } \\
\text { back ground }\end{array}$} & Read and write & 43 & 21 & 26 & 38 & 15 & 8 & 151 & 25 \\
\hline & primary first cycle & 35 & 13 & 18 & 28 & 9 & 10 & 113 & 19 \\
\hline & primary second cycle & 8 & 3 & 1 & 7 & 4 & 2 & 25 & 4 \\
\hline & secondary school & 2 & 1 & 3 & 3 & 1 & 2 & 12 & 2 \\
\hline & Not attend any school & 56 & 26 & 34 & 46 & 72 & 65 & 299 & 50 \\
\hline & Total & 144 & 64 & 82 & 122 & 101 & 87 & 600 & 100 \\
\hline
\end{tabular}

Source: Households survey

\subsection{Socio-economic Characteristics of Sample Households}

The findings indicate that the majority (55\%) of households had stayed in the study site for more than 15 years. The remaining of households $(17 \%)$ has stayed for $11-15$ years and $16 \%$ for $6-10$ years and (12\%) have stayed for five year (table 4). Therefore, higher proportion of the sampled household heads at study site was native to the area. The result of the total annual income of the respondents was indicated (table 4). Most respondents are not high income earners and therefore cannot be able to source labor for a fee to manage their agroforestry practices. For this reason they use their family lobour. The study was not similar to that of Gedeo, Southern Ethiopia, a study and analyzing factors that affect the implementation of agroforestry practices agrees that income has a positive correlation with agroforestry practices [16]. From tables four we can understand most of the households (45\%) have land holding size of $0.25-0.5$ ha. Most of the farmers who were more likely to practices traditional agroforestry had smaller hectares of land size. This, is not consistent with study carried out in Debark District, northern Ethiopia" an increase of farm size by one hectare, increases the probability of practices agroforestry" [17]. It can be indicated that mixed farming was the main type of traditional farming system in study site. Higher proportions of the respondents have livestock number between 1-5 which is manageable around small land and with family lobour (table 4).

Table 4. Socio-economic Characteristics of sample households.

\begin{tabular}{|c|c|c|c|c|c|c|c|c|c|}
\hline \multirow{2}{*}{$\begin{array}{l}\text { Socio-economic } \\
\text { variable }\end{array}$} & \multirow{2}{*}{$\begin{array}{l}\text { Definition of } \\
\text { variables }\end{array}$} & \multicolumn{6}{|c|}{ Sample districts in study site } & \multirow{2}{*}{ Total } & \multirow{2}{*}{$\begin{array}{l}\text { \% of } \\
\text { Respondents }\end{array}$} \\
\hline & & Gemechis & Hancar & Darolabu & Odabultum & Mieso & Burkdhimtu & & \\
\hline \multirow{6}{*}{$\begin{array}{l}\text { HH stayed time in } \\
\text { farming }\end{array}$} & $0-5$ rears & 23 & 11 & 15 & 13 & 10 & 6 & 78 & 12 \\
\hline & 6-10 & 21 & 11 & 14 & 19 & 16 & 13 & 94 & 16 \\
\hline & $11-15$ & 26 & 8 & 4 & 21 & 21 & 20 & 100 & 17 \\
\hline & $>15$ & 74 & 34 & 49 & 69 & 54 & 48 & 328 & 55 \\
\hline & Total & 144 & 64 & 82 & 122 & 101 & 87 & 600 & 100 \\
\hline & $1000-4000$ birr & 85 & 31 & 35 & 67 & 76 & 68 & 362 & 60 \\
\hline \multirow{4}{*}{$\begin{array}{l}\text { HH monthly } \\
\text { income in Birr }\end{array}$} & $5000-8000$ & 30 & 23 & 39 & 24 & 14 & 10 & 140 & 23 \\
\hline & $9000-12000$ & 15 & 6 & 6 & 20 & 7 & 6 & 60 & 10 \\
\hline & $>12000$ & 14 & 4 & 2 & 11 & 4 & 3 & 38 & 7 \\
\hline & Total & 144 & 64 & 82 & 122 & 101 & 87 & 600 & 100 \\
\hline \multirow{5}{*}{$\begin{array}{l}\text { HH land size in } \\
\text { hectare }\end{array}$} & $0.25-0.5$ & 106 & 26 & 33 & 83 & 19 & 5 & 272 & 45 \\
\hline & $0.5-1$ & 26 & 26 & 39 & 24 & 58 & 61 & 234 & 40 \\
\hline & $1-2$ & 7 & 6 & 5 & 8 & 20 & 16 & 62 & 10 \\
\hline & $>2$ & 5 & 6 & 5 & 7 & 4 & 5 & 32 & 5 \\
\hline & Total & 144 & 64 & 82 & 122 & 101 & 87 & 600 & 100 \\
\hline \multirow{6}{*}{$\begin{array}{l}\text { Number of animals } \\
\text { keep by HH }\end{array}$} & $1-3$ & 80 & 33 & 48 & 60 & 4 & 7 & 232 & 39 \\
\hline & $4-5$ & 32 & 17 & 24 & 31 & 41 & 38 & 183 & 31 \\
\hline & $5-10$ & 15 & 3 & 7 & 14 & 30 & 27 & 96 & 16 \\
\hline & $>10$ & 7 & 10 & 3 & 6 & 26 & 15 & 67 & 11 \\
\hline & No & 10 & 1 & 0 & 11 & 0 & 0 & 22 & 4 \\
\hline & Total & 144 & 64 & 82 & 122 & 101 & 87 & 600 & 100 \\
\hline
\end{tabular}

Source: Households survey 


\subsection{Management Practices in Traditional Agroforestry Practices}

There were different kinds of management observed in traditional agroforestry practice of West Hararghe zone. In general, the criterion used to select some management practice in the zone is mainly to reduce negative interaction between components and maximize the overall function of the system per land management unit. Consequently, management practices in home garden and woodlot are mainly given to increase fruit products and market values, respectively while in parkland it is given to increase survival and yield of agricultural products tree canopy. The common management practices include branch pruning, coppicing, thinning, pollarding, protection from animal and human damage, and prescribed burning.

From the common management practices in the study site, (30\%) of brunch pruning, $(25 \%)$ of coppicing, and $(29 \%)$ of protection from animal intervention and (38\%) thinning, is applied in mixed intercropping compared to others traditional agroforestry practices. pruning (43\%), coppicing $(40 \%)$ and protection from animal intervention (20\%), are implemented in homegarden. In MPTs in cropland include brunch pruning $(37 \%)$, thinning $(8 \%)$, coppicing $(10 \%)$, pollarding $(44 \%)$ and protection from animal intervention (16\%). Brunch pruning (27\%), pollarding (20\%) and protection from animal intervention (30\%), are implemented in live fence/boundary planting. Pollarding (32\%), coppicing (20\%), protection from animal intervention (28\%) and prescribed burning (35\%) are implemented in trees in grazing land. Similarly, brunch pruning (33\%), thinning (34\%), coppicing (38\%) and prescribed burning $(28 \%)$ are implemented in multipurpose woodlots and (28\%) of protection from animal intervention in trees in soil conservation and reclamation.

Both Key informant interviews and focus group discussions respondent mentioned an existence of management variations among traditional agroforestry practices. Burning was given for only woodlots and trees in rangeland. The application of any management scheme in the area is linked with the traditional knowledge of the people in the study site. They perceive how well the woody species react to different managements. For instance, prescribed burning was only given for woodlot. High practice of pollarding in MPTs in crop land and trees in rangeland is attributed to the need of light by the associated crops in practices than others. Relatively high practice of coppicing in mixed intercropping, homegarden, woodlots and trees in rangeland is taking place. Most of the trees species exist in these agroforestry practices are coppicing species. The reason of coppicing is mainly related to the desire of land owners to get regeneration of new shoots from the stamp to optimize the productivity. Relatively no thinning and less coppicing in MPTs in crop land and trees in rangeland is attributed to the low tree density composition in the component. In general, variation in the management intensity was observed in the study site, and this is also true in different areas and ecoregions [1].

\subsection{Woody Species Recorded in Traditional Agroforestry Practices}

\subsubsection{Trees in Mixed Intercropping Agroforestry Practices}

Researchers can draw on farmer's knowledge when deciding which species to make available for farmers for intercropping with cereals and further more use this as a baseline for further research in understanding physiological trees good for intercropping with cereals. Farmers identified tree species which are good for intercropping with cereals and the dominant woody species in the area are Catha edulis (51\%), Sesbania sesban (37\%) and Ferdahbia albida (36\%) (table 5). Besides, farmers in the study area have experiences of intercropping of multipurpose trees with crops such as, Acacia abyssinic, Olea africana, Croton macrostachyus and Juniperus procera which agrees with the findings. In most African highland, Ferdahbia albida, Acacia saligana, Sesbania sesban, Lucean lucocephala are preferred for their qualities to improve soil fertility [18]. The result is also similar with the findings of the study conducted at similar agroecological [19]. Furthermore, the tree species found in mixed intercropping traditional agroforestry are listed in table 5 .

Table 5. Trees on mixed intercropping agroforestry practices.

\begin{tabular}{lllll}
\hline No & Local name & Scientific Name & Frequency & $\begin{array}{l}(\%) \\
\text { respondents }\end{array}$ \\
\hline 1 & Lafto & Acacia abyssinica & 43 & 21 \\
2 & Daree & Acacia etbaica & 54 & 26 \\
3 & Akacha saligna & Acacia saligana & 35 & 17 \\
4 & Sabansa dima & Acacia Senegal & 30 & 14 \\
5 & Buchema & Buddleja polystacha & 24 & 12 \\
6 & Jimaa & Catha edulis & 106 & 51 \\
7 & Wadesa & Cordia Africana & 65 & 31 \\
8 & Bakanisa & Croton & 46 & 22 \\
9 & Gantira faranji & Cupressus lusitanica & 31 & 15 \\
10 & Danissa & Dombeya torrid & 16 & 8 \\
11 & Bargamo dima & Eucalyptus & 34 & 16 \\
12 & Gerbi & camaldulensis & & \\
13 & Hindesa & Juniperus procera & 28 & 36 \\
14 & Lukina & Lucean lucocephala & 64 & 31 \\
15 & Ejersa & Olea Africana & 42 & 20 \\
16 & Adesa & Rhus glutinosa & 21 & 10 \\
17 & Harcha & Sesbania sesban & 76 & 37 \\
\hline
\end{tabular}

Source: Households survey

\subsubsection{Trees on Homegarden}

Homegardens refer to the cultivation of plants, husbandry of livestock and other farming activities around the farmers' homesteads to satisfy multiple needs, mainly food, and to generate extra income [20]. In west Haraghe zone in general and study peasant association in particular homegarden are the widely practiced traditional agroforestry activities. It is very common to observe multipurpose trees and fruit trees in the backyard of many households. A total of 24 species in 
varies families were recorded in the homegarden traditional agroforestry practices (table 6). Fruits like Persea Americana (35\%), Psidium guajava (31\%) and Citrus aurantifolia (16\%) are also serving as sources of supplementary food and income generation opportunities. Most of woody plant species which are found in the studied home garden were frequently cited in other related studies. For example, Persea Americana, Cordia africana, Coffee arabica, Mangifera indica, Millettia ferruginea, Catha edulis, Ficus vasta, Psidium guajava were reported in South Gonder Zone, North West Ethiopia [21]. The result of this finding was also in line with that reported on coffee agroforestry systems in the Hararghe highlands of eastern Ethiopia and identified native trees, such as Albizia gummifera, Acacia abyssinica, Millettia ferruginea, Ficus sur, Ficus vasta and Cordia Africana which are uses for coffee shade [22]. Furthermore, the tree species found in home garden traditional agroforestry are listed in table 6 .

Table 6. Trees on Home garden.

\begin{tabular}{lllll}
\hline No & Local name & Scientific Name & Frequency & $\begin{array}{l}(\%) \\
\text { respondents }\end{array}$ \\
\hline 1 & Akacha & Acacia decurrense & 42 & 24 \\
2 & Kasale & Acacia nilotica & 59 & 34 \\
3 & Mukaarba & Albizia gummifera & 62 & 36 \\
4 & Gumero & Capparis tomentosa & 42 & 24 \\
5 & Jimaa & Catha edulis & 54 & 31 \\
6 & Lomi & Citrus aurantifolia & 27 & 16 \\
7 & Tiringo & Citrus medica & 24 & 14 \\
8 & Birtukana & Citrus sinensis & 26 & 15 \\
9 & Buna & Coffee Arabica & 31 & 18 \\
10 & Dandamsa & Combretum molle & 26 & 15 \\
11 & Wadessa & Cordia Africana & 51 & 30 \\
12 & Bakanisa & Croton macrostachyus & 21 & 12 \\
13 & G/faranji & Cupressus lusitanica & 31 & 18 \\
14 & Gishxa & & 41 & 24 \\
15 & Bahirzaf adi & Eucalyptus glublus & 37 & 22 \\
16 & Qilxu & Ficus vasta & 20 & 12 \\
17 & Hindessa & Juniperus procera & 32 & 19 \\
18 & Tumuga & Justicia schimperiana & 33 & 19 \\
19 & Mango & Mangifera indica & 72 & 42 \\
20 & Birbira & Millettia ferruginea & 51 & 30 \\
21 & Ejersa & Olea Africana & 31 & 18 \\
22 & Avocado & Persea Americana & 60 & 35 \\
23 & Zeituna & Psidium guajava & 54 & 31 \\
24 & Aebicha & Vernonia amygdalina & 51 & 30 \\
\hline & & & &
\end{tabular}

Source: Households survey

\subsubsection{MPTs Trees on Cropland}

Multipurpose trees on farmlands refer to the deliberate integration of woody components in annual croplands, which is the case in almost all observed farmlands in the study area. In these systems, the primary purpose is the production of annual food crops for consumption and/or selling, whereas the uses of woody plant species are as non-food goods, e.g., fuel, fodder, timber, etc., and services, e.g. live fences for protection and demarcation, soil fertility enhancement, shade, etc [23]. Mainly the trees on this traditional agroforestry are trees that are naturally grown, large in size and are very scattered. Twenty three woody plant species were recorded in the MPTs trees on cropland traditional agroforestry practices (table 7). The five most frequent tree species in MPTs trees on cropland traditional AF systems were Ferdahbia albida (58\%), Cordia Africana (56\%), Sesbania sesban (51\%), Millettia ferruginea (47\%) and Acacia abyssinica (45\%) Whereas, Psydrax schimperiana (7\%), Eucalyptus globules (7\%), Eucalyptus camaldulensis (8\%), Juniperus procera $(8 \%)$, and Cupressus lusitanica $(9 \%)$ are the lowest woody species selected for this traditional agroforestry practices (table 7).

Farmers branded a number of indigenous and exotic species as potentially undesirable within and around croplands. The overwhelming majority of the households rated eucalypt species as the most undesirable species in croplands primarily for intense competition with food crops and drying up of the soil, Juniperus procera and Cupressus lusitanica are the next most disliked tree species mainly for their drying up effects on the soil and intense competition with crops. The most frequently mentioned species in this traditional agroforestry were consistent with the findings of study carried out in the Hararghe highlands of Eastern Ethiopia that identified the oldest traditional agroforestry systems retention of scattered apple-ring Acacia (Faidherbia albida) on farmlands [24]. Furthermore, the tree species found in MPTs on crop land traditional agroforestry are listed in table 7.

Table 7. MPTs on crop land.

\begin{tabular}{|c|c|c|c|c|}
\hline No & Local name & Scientific Name & Frequency & $\begin{array}{l}(\%) \\
\text { respondents }\end{array}$ \\
\hline 1 & Lafto & Acacia abyssinica & 67 & 45 \\
\hline 2 & Bamba dima & Adansonia digitata, & 34 & 23 \\
\hline 3 & Muka arta & Albizia scimperiana & 45 & 30 \\
\hline 4 & Buchema & Buddleja polystacha & 23 & 16 \\
\hline 5 & Mateqoma & Celtis Africana & 32 & 22 \\
\hline 6 & Chlanka & $\begin{array}{l}\text { Commiphora } \\
\text { haberssinica }\end{array}$ & 24 & 16 \\
\hline 7 & Wadesa & Cordia africana & 83 & 56 \\
\hline 8 & Bakanisa & Croton macrostachys & 27 & 18 \\
\hline 9 & $\mathrm{G} /$ faranji & Cupressus lusitanica & 14 & 9 \\
\hline 10 & Itancha & Dodonea angustifolia & 40 & 27 \\
\hline 11 & Danissa & Dombeya torrid & 36 & 24 \\
\hline 12 & $\begin{array}{l}\text { Bargamo } \\
\text { dima }\end{array}$ & Eucalyptus camaldulensis & 12 & 8 \\
\hline 13 & Bargamo adi & Eucalyptus globules & 10 & 7 \\
\hline 14 & Garbi & Ferdahbia albida & 86 & 58 \\
\hline 15 & Hindessa & Juniperus procera & 12 & 8 \\
\hline 16 & Tumuga & Justicia schimperiana & 37 & 25 \\
\hline 17 & Ule farad & Leonotis ocymifolia & 30 & 20 \\
\hline 18 & Birbira & Millettia ferruginea & 70 & 47 \\
\hline 19 & Raji abay & Myrica salicifolia & 26 & 18 \\
\hline 20 & Ejersa & Olea Africana & 39 & 26 \\
\hline 21 & Qadis & Olinia rochetiana & 18 & 12 \\
\hline 22 & Harcha & Sesbania sesban & 76 & 51 \\
\hline 23 & Aebicha & Vernonia amygdalina & 46 & 31 \\
\hline
\end{tabular}

Source: Households survey

\subsubsection{Trees in Live Fences/Boundary Planting}

Woody tree species are planted around a house and cropland and garden. The objective of live fence and boundary planting is to provide protection and shelter against domestic animals, wind and sun. But, beside the deliberate 
benefits of as fencing, trees are providing fuel wood, shade for human and livestock and fodder. In these traditional agroforestry practices the overall percentage of occurrence of woody species varied between (5\%-39\%). Totally 20 species were recorded (table 8). Juniperus procera (39\%) was the highest and Justicia schimperiana (5\%), was less frequently encountered than the other woody species (Table 9). Besides, Eucalyptus globulus, Olea africana, Allophylus abyssinicus, Cupressus lusitanica, Eucalyptus camaldulensis, Accacia saligna, Dovyalis abyssinica, Justicia schimperiana, Lucean lucocephala, Acacia brevispica, and Euphorbia abyssinica are good candidates and practices for live fence/boundary planting according to farmers. During, focus group discussion farmers Saied mostly the tree species in this traditional agroforestry practices are thorny like. However farmers informed that using some species such Eucalyptus species and Cupressus lusitanica care should be taken due to their adverse effect on agricultural crops. Similar findings were reported from farmers' perspective benefits, growing eucalyptus far outweighs ecological costs from its impacts under the current market condition; eucalyptus growing provides far better return on investment than any alternative land uses [25]. Furthermore, the tree species found in trees on Multi-purpose woodlots traditional agroforestry are listed in table 8 .

Table 8. Trees on Live fence/Boundary planting.

\begin{tabular}{lllll}
\hline No & Local name & Scientific Name & Frequency & $\begin{array}{l}(\%) \\
\text { respondents }\end{array}$ \\
\hline 1 & Kontur & Acacia brevispica & 17 & 14 \\
2 & Lafto adi & Acacia sieberiana & 23 & 19 \\
3 & Akacha saligna & Accacia saligna & 21 & 18 \\
4 & Lafto Wacho & Acecia seyal & 30 & 25 \\
5 & Seho & Allophylus & 18 & 15 \\
6 & Badano & abyssinicus & & \\
7 & Agamsa & Calanites aegyptiaca & 7 & 6 \\
8 & Gantira faranji & Cupressus lusitanica & 19 & 32 \\
9 & Koshim & Dovyalis abyssinica & 25 & 21 \\
10 & Bargamo dima & Eucalyptus & 24 & 20 \\
& & camaldulensis & & \\
11 & Bargamo adi & Eucalyptus globules & 26 & 22 \\
12 & Adami & Euphorbia abyssinica & 21 & 18 \\
13 & Gerbi & Ferdahbia albida & 37 & 31 \\
14 & Giravilia & Giravilia robusta, & 32 & 27 \\
15 & Hindhesa & Juniperus procera & 46 & 39 \\
16 & Tumuga & Justicia schimperiana & 6 & 5 \\
17 & Lukina & Lucean lucocephala & 26 & 22 \\
18 & Ejarsa & Olea Africana & 19 & 16 \\
19 & Harcha & Sesbaina sesban, & 38 & 32 \\
20 & Qurqura & Ziziphus spina-christi & 14 & 12 \\
\hline & & & & \\
\hline
\end{tabular}

Source: Households survey

\subsubsection{Trees in Multipurpose Woodlots}

A woodlot is a small patch of land planted with trees on farm and can be also planted in common lands for the benefit of the community. It can involve mixture of the species and would serve as sources of fuel wood, fodder, construction materials and other tree products while reclaiming the marginal lands. In study site establishment of the woody species in the form of woodlots in order to fulfill multiple objectives (wood, fodder, soil protection, soil reclamation, etc.), were practiced. The species listed in (table 9) below have potential to be used in this respect. Similarly the College of Agriculture (now Haramaya University) was reported in the Aforestation and Soil Conservation program in the early 1980s. One the main objectives of the community forestry project were, to establish community woodlots to meet the demands of fuel wood, construction materials, and fodder from trees planted outside forests woody species. Seedlings raised during the 1979/1980 planting season were, Acacia species, Casurainae euistifolia Cupressus lustanica, Eucayptus camaldulensis Eucalyptus globules, Eucalyptus saligna, Grevillia robusta [19]. Furthermore, the tree species found on Multi-purpose woodlots traditional agroforestry are listed in table 9.

Table 9. Trees on Multi-purpose woodlots.

\begin{tabular}{lllll}
\hline No & Local name & Scientific Name & Frequency & $\begin{array}{l}(\%) \\
\text { respondents }\end{array}$ \\
\hline 1 & Akacha & Acacia decurrense & 23 & 28 \\
2 & Kasale & Acacia nilotica & 14 & 17 \\
3 & Hallo & Acecia bussei & 12 & 14 \\
4 & Sabansa dima & Acecia Senegal & 18 & 22 \\
5 & Tedecha & Acecia tortilis & 15 & 18 \\
6 & Shawshawe & Casurainae euistifolia & 24 & 29 \\
7 & Gantira faranji & Cupressus lusitanica, & 20 & 24 \\
8 & Bargamo dima & Eucalyptus & 35 & 42 \\
9 & Bargamo adi & Eumaldulensis, & & \\
10 & Bargamo saligna & Eucalyptus saligna, & 21 & 25 \\
11 & Gerbi & Ferdahbia albida & 30 & 36 \\
12 & Gravilia & Grevillia robusta & 25 & 30 \\
13 & Hindhesa & Juniperus procera & 26 & 31 \\
14 & Lukina & Lucean lucocephala & 20 & 24 \\
\hline
\end{tabular}

Source: Households survey

\subsubsection{Trees on Soil Conservation/Rehabilitation}

Soil and water conservation has been practiced in many parts of Ethiopia, and it has been promoted by the governments (the past and present) for more than 20 years. It is thus increasingly becoming a culture in many areas. In this light, tree species have a lot to contribute. Traditionally, they have been incorporated in many of the conservation earthwork structures - especially, soil and stone bunds. Furthermore, they can be grown on terraces, for the purpose of reclamation of degraded soils, and stabilization while providing various tree products Such as fodder, fruit or fuel wood. This makes productive use of the land because trees would use the area along the structures where other crops cannot be grown. Woody tree species to be promoted for this purpose include: Acacia abyssinica, Acacia etbaica Acacia saligina, Sesbaina sesban, Delonix regia, Acacia seyal, Grevillea robusta, Eucalyptus camaldulensis, Fiaderbia albida Millettia ferruginea, Lucean lucocephala and Ziziphus spina-christi were woody species that practiced for these purpose. Furthermore, the tree species found in degraded land traditional agroforestry practices are listed in table 10 . 
Table 10. Trees on soil conservation/Rehabilitation.

\begin{tabular}{lllll}
\hline No & Local name & Scientific Name & Frequency & $\begin{array}{l}(\%) \\
\text { respondents }\end{array}$ \\
\hline 1 & Lafto & Acacia abyssinica & 32 & 37 \\
2 & Daree & Acacia etbaica & 21 & 24 \\
4 & Akacha saligna & Acacia saligina & 21 & 24 \\
5 & Lafto Wacho & Acacia seyal, & 17 & 20 \\
3 & Tedecha & Acacia tortilis & 17 & 19 \\
6 & Niim & Azadirachta indica & 7 & 8 \\
9 & Badano & Balanites aegyptiaca & 16 & 18 \\
10 & Wadesa & Cordia Africana & 13 & 15 \\
11 & Mukadiredawa & Delonix regia & 19 & 22 \\
7 & Girmi & Dichrostchus cenearea & 9 & 10 \\
8 & Itancha & Dodonea angustifolia & 13 & 15 \\
12 & Bargamo dima & Eucalyptus & 26 & 30 \\
13 & Dadaho & camaldulensis, & & \\
14 & Gerbi & Fiaderbia albida & 30 & 33 \\
15 & Gravilia & Grevillea robusta, & 22 & 25 \\
16 & Tumuga & Justicia schimperiana, & 16 & 18 \\
17 & Lukina & Lucean lucocephala & 22 & 25 \\
18 & Birbira & Millettia ferruginea & 19 & 22 \\
19 & Harcha & Sesbaina sesban & 20 & 23 \\
20 & Aebicha & Vernonia amygdalina, & 16 & 18 \\
21 & Qurqura & Ziziphus spina-christi & 17 & 20 \\
\hline
\end{tabular}

Source: Households survey

\subsubsection{Scattered Trees on Grazing Lands}

The production of woody plants combined with rangeland is often referred to as scattered trees on grazing lands agroforestry system. Tree planting on grazing lands is not a common practice in study areas. However, deliberate protection and management of the naturally grown trees on grazing land is a common practice, because naturally grown trees on grazing lands have several benefits such as fuel wood, construction materials, and fodder and improve the soil. The following are tree species identified by field observation and interview (table 11). Different from other traditional agroforestry, the trees identified on this practice are very large in size and are very scattered (Table 11).

Table 11. Trees on grazing lands.

\begin{tabular}{lllll}
\hline No & Local name & Scientific Name & Frequency & $\begin{array}{l}(\%) \\
\text { respondents }\end{array}$ \\
\hline 1 & Lafto & Acacia abyssinica & 11 & 24 \\
2 & Kasale & Acacia nilotica & 14 & 31 \\
3 & Garbi ala & Acacia mearnsi & 8 & 18 \\
4 & Bamba dima & Adansonia digitata & 5 & 12 \\
5 & Mukaarba & Albizia gummifera & 15 & 33 \\
6 & Mateqoma & Celtis Africana & 4 & 10 \\
7 & Dandamsa & Comberutum molle & 2 & 5 \\
8 & Wadesa & Cordia Africana & 8 & 18 \\
9 & Bakanisa & Croton macrostachys & 5 & 12 \\
10 & Wolensu & Erythrina abyssinica & 7 & 15 \\
11 & Gerbi & Fiaderbia albida & 15 & 34 \\
12 & Harbu & Ficus sur & 9 & 21 \\
13 & Oda & Ficus sycomorus & 13 & 30 \\
14 & Qilxu & Ficus vasta, & 11 & 25 \\
15 & Birbira & Millettia ferruginea & 9 & 20 \\
& & Olea Africana & 7 & 15 \\
\hline
\end{tabular}

Source: Households survey
Generally, a number of Compositions of woody species in traditional agroforestry practices in study site were observed and counted. The frequency of planting of these species is quite different among households and some woody species are more commonly planted than others among traditional agroforestry practices. In total, 68 woody tree species representing 31 families were recorded in this study. Of the total, $20(29.4 \%)$ species belong to the family Fabaceae, 6 species to Myrtaceae, 5 species to Rubiaceae, 3 species to each Euphorbiaceae Moraceae and Oleaceae, 2 species to each Anacardiaceae Cupressaceae and Sapindaceae and 22 families are represented by a single species. 18 species are introduced for traditional agroforestry purposes, 2 species are endemic to Ethiopia and the remaining majority 48 indigenous species are practiced by obtaining their seeds and seedlings either from different sources.

Similar, traditional agroforestry systems are practiced in different parts of the country. A total of 120 trees from 144 coffee based homegarden in four districts of Sidama, southern Ethiopia were reported [26]. The woody species in this agroforestry system were mainly Cordia africana, Eucalyptus camaldulensis, Millettia ferruginea and Euphorbia candelabrum. In south-eastern Ethiopia, 90 woody species including native tree species such as Juniperus procera, Olea europaea subsp, Podocarpus falcatus, Acacia tortilis and Hagenia abyssinica was identified [27].

\section{Conclusion and Recommendations}

\subsection{Conclusion}

The current study have shown that there are varies traditional agroforestry management practices in west Hararghe zone. Woody plant species identified and recorded shown, that there are huge potentials for agroforestry development in the study area. The study has recorded 68 woody tree species, many of them belonging to the family Fabaceae. Therefore, traditional, agroforestry practice could be one option to improve small farmer's life in study site.

\subsection{Recommendations}

Traditional agroforestry practices were observed, however, identifying representative sites to undertake detailed studies on improving existing and introducing new agroforestry systems is needed. The traditional knowledge on agroforestry system and practice management being applied in the study site should have to get recognition. Research should explore the local species that could be of interest to the farmers and help in propagation of seedlings of traditional species which may be of interest to farmers. Woody tree species in effect on crops yields are not properly documented. Therefore, it is important to study the dominant woody species effect on crop productivity. The study recommends that the existing woody plant species should be conserved than the current status by planting seedling. 


\section{References}

[1] Bishaw, B., and A. Abdelkadir. 2003. Agroforestry and Community Forestry for Rehabilitation of Degraded Watersheds on the Ethiopian Highlands. International Symposium on Contemporary Development Issues in Ethiopia, July 11-12, 2003, Addis.

[2] Kebede, T. M. (2010). Homegardens agrobiodiversity conservation in Sebeta-Hawas Wereda, Southwestern Shewa Zone of Oromia Region, Ethiopia.

[3] World Agroforestry Centre (ICRAF) (2006) Agroforestry for improved livelihoods and Natural resources conservation. An Agroforestry Policy Brief. Kenya, Nairobi.

[4] Jama B, Zeila A (2005) Agroforestry in the drylands of eastern Africa: a call to action. ICRAF Working Paper - no. 1. Nairobi: World Agroforestry Centre.

[5] Teshome A (2006) Agriculture, Growth and Poverty Reduction in Ethiopia: Policy Processes around the New PRSP (PASDEP). A paper for the Future Agricultures Consortium workshop, Institute of Development Studies.

[6] Nair, P. K. 1993. An introduction to Agroforestry: pp 13-155, ICRAF/Kluwers Academic Publishers, Dordrecht, The Netherlands.

[7] Miller, R. P., and Nair, P. K. R. (2006). Indigenous agroforestry systems in Amazonia: from prehistory to today. Agroforestry Systems 66, 151-164.

[8] Oudwater N, Martin A (2003) Methods and issues in exploring local knowledge of soil. Geoderma 111: 387-401.

[9] King KFS (1980) Agroforestry and development of tropical forestry. UNEP, meeting of experts on tropical forests. Nairobi.

[10] WHZBOFED (West Harerghe Zone Finance and Economic Development Office), 2010. Annual Report. 54p.

[11] CSA (Central Statistical Authority), 2007. Population and Housing Census Survey, Addis Ababa, Ethiopia. 121p.

[12] Israel, G. D. 2013. Determining sample size. http://edis.ifas.ufl.edu/pdfles/PD/PD00600.pdf.

[13] Martin, G. J. 1995. Ethnobotany. A people and plants conservation manual. London: Chapman and Hall.

[14] Azene, B. 2007. Useful trees and shrubs of Ethiopia: Identification, propagation, and management in 17 Agroecological zones. Nairobi: in ICRAF Project, 552pp.

[15] Natural Database for Africa (2011) digital guideline.
[16] Negash, M., and N. Achalu. 2008. History of indigenous agroforestry in Gedeo, Southern Ethiopia, based on local community interviews: Vegetation diversity and stucture in the land-use http://agris.fao.org/aos/records/ET2009000185. systems.

[17] Tefera, B., M. L. Ruelle, Z. Asfaw, and B. A. Tsegay. 2014. Woody plant diversity in an Afromontane agricultural landscape (Debark District, northern Ethiopia). Forests, Trees and Livelihoods $23 \quad$ (4): 261-279. http://dx.doi.org/10.1080/14728028.2014.942709.

[18] Berhane Kidane, Kindu Mekonnon, Fekede Feyissa, Chilot Yirga (2004). African Highland Initiative, Integrated natural resource management in practice: Enabling communities to improve mountain livelihoods and landscapes.

[19] Bishaw, B., and Abdelkadir, A. 1989. Strategies for On-Farm Research in Agroforestry in Hararghe Highlands, Eastern Ethiopia. In IAR Proceeding, First Natural Resources Conservation Conference. Addis Ababa, Ethiopia, 164-173.

[20] Abiyu, A., D. Teketay, G. Gratzer, and M. Shete. 2015. Tree planting by smallholder farmers in the upper catchment of Lake Tana watershed, northwest Ethiopia, Small-scale Forestry.

[21] Abreha Asefa Gebrekidan Worku 2014: Woody Plant Inventory and Diversity in Traditional Agroforestry of Selected Peasant Association of South Gonder Zone, North West Ethiopia.

[22] Mersha Gebrehiwot. 2013. Recent Transitions in Ethiopian home garden agroforestry: Driving forces and changing gender relations. Licentiate Thesis. Swedish University of Agricultural Sciences, Umea. 53p.

[23] Gebreegziabher Z, Mekonnen A, Kassie M, Köhlin G (2010) Household Tree Planting in Tigrai, Northern Ethiopia: Tree Species, Purpores, and Determinants. Environment for development, January, 2010.

[24] Poschen, P. 1986. An evaluation of the Acacia albida-based agroforestry practices in the Hararghe highlands of Eastern Ethiopia, Agroforestry Systems 4: 129-143.

[25] Lemenih, M., and H. Kassa. 2014. Re-greening Ethiopia: History, challenges and lessons. Forests 5 (7): 1717-1730. doi: $10.3390 /$ f5071717.

[26] Abebe, T., Wiersum, K. F., Bongers, F. \& Sterck, F. 2006. Diversity and dynamics in homegardens of southern Ethiopia. In: B. M. Kumar \& P. K. R. Nair (Eds.). Tropical homegarden: a time-tested example of sustainable agroforestry, p. 123-142.

[27] Mengesha, B. 2010. Alternative technologies for sustainable agricultural production and agroecosystem conservation in Arsi highlands, south-eastern Ethiopia. PhD thesis. Addis Ababa University, Ethiopia. p. 198. 